\title{
MARRIAGE CANCELLED, WHAT ABOUT THE RIGHTS FOR CHILDREN?
}

\author{
Analysis of the Legal Consequences of Marriage \\ Cancellation Due to Polygamy Without Permission from the \\ Religious Courts and Decisions Against Children's Rights
}

\author{
Maryana Lestari \\ Faculty of Law, Universitas Muhammadiyah Yogyakarta, Indonesia \\ Septhian Eka Adiyatma \\ Faculty of Law, Universitas Negeri Semarang, Indonesia \\ Email: septhianekaa@gmail.com
}

\begin{abstract}
Marriage regulations have been regulated in detail through Law No. 16 of 2019 which is a renewal of Law No. 1 of 1974 regarding marriages in several articles changed and followed by other supporting rules. In the Republic of Indonesia the marriage system adheres to the concept of absolute monogamy, only for the marriage of one husband and one wife. As a result of cultural and religious uniformity, there is a difference in the application of law in Indonesia, the application of national law that applies the concept of absolute monogamy is the implementation of Christian religion. Islam also contributes to the organization of marriages by regulating marriages in Presidential Instruction No. 1 of 1991 concerning the Compilation of Islamic Law (KHI), this illustrates that the contribution of Islam is recognized by the state. Knowing the word polygamy is only recognized through the rules contained in Islam, but the requirements for polygamy are permitted in Indonesia only to husbands. Opponents of a polygamy marriage are polyandry marriages, the difference is seen from the side of the husband or wife who has more than 1 partner. Although it is permissible under the applicable law all the requirements required by the state must be fulfilled as a whole, some of these requirements include obtaining permission from a legal wife or prospective wife to be combined, a statement of being able to be fair, as well as other accessible requirements in the competent authority.
\end{abstract}

Keywords: Marriage Cancellation; Polygamy; Children's Rights

The Indonesian Journal of International Clinical Legal Education ISSN 2721-8368

DOI: 10.15294/ijicle.v2i2.38172

(C) 2020 Authors. This work is licensed under a Creative Commons Attribution-ShareAlike 4.o International License. All writings published in this journal are personal views of the authors and do not represent the views of this journal and the author's affiliated institutions.

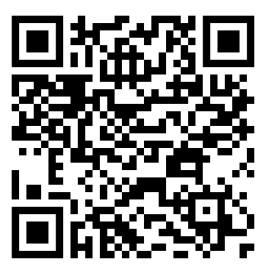




\section{INTRODUCTION}

Marriage according to Yahya Harapan is detailed, as marriage is an inner and outer bond between a man and woman as husband and wife, the inner and outer bonds are to form a happy, eternal and prosperous home family; the basis of inner and outer bonds and the eternal purpose of happiness in the Almighty God.

Marriage is a legal event in which raises the rights and obligations resulting from the emergence of legal relations and is followed by the legal consequences of the act. The concept of absolute monogamy refers to every citizen in Indonesia allowed to have a marriage in which only one husband and one wife are married. The legal basis for marriage is contained in the provisions of Law No. 1 of 1974 and changed to Law No. 16 of 2019 with a few changes therein which is located in article 7 and article 65 and article 66 is inserted into article $65 \mathrm{~A}$.

As a rule of law, running a state life is very much determined by regulations. This also applies to marriages, although marriages are private acts but the rules are regulated overall so to say a marriage will be considered valid if it meets the legal, religious and belief requirements adopted by the person concerned. By being governed by the law of the position of religion and belief remain in the highest position, everything related to marriage will always be associated with religion and belief.

Human rights granted by the state, namely the right to form a family and the right to continue their descendants through a marriage that is considered legal by the state and religion, this right is contained in article $28 \mathrm{~B}$ of the 1945 Constitution of the Republic of Indonesia. Basically, marriage is intended a long period of time even the words that are often known to the marriage community until death separates.

However, marriages can end because of several things including one of them died, due to divorce and the marriage was canceled. Divorce can occur if there is a will from both the husband and wife due to the marriage being endured there is no harmony again. So that the only way to solve this problem is only by divorce. The phenomenon under study is the end of the marriage due to the cancellation of the marriage. Marriage can be canceled if the parties including husband and wife do not meet the requirements. Both divorce and annulment of marriage both have their own legal consequences.

Inevitably, chaos in domestic life will occur. The impact will always be on women and children. Marriage chaos can be interpreted as a split in a family, one of which is even both husband and wife failing to carry out their obligations and roles in the household. Neither divorce nor annulment of marriage is prohibited by the state but if it is examined with the view of religion both actions are prohibited.

So that the rules for doing so are determined by the state which must comply with certain requirements, such as the following requirements for divorce if one of the husband and wife is a drunkard, 
gambler compactor and other symptoms with indications of difficulty in being cured due to dependence, then left for 2 (two) years without a valid reason and beyond the ability, one of which is sentenced to more than 5 (five) years and even convicted with a heavier sentence, dangerous violence occurs that is dangerous, get disabled so that obligation s cannot be fulfilled, and there is no hope for a harmonious life.

Conditions for cancellation of a marriage can be fulfilled, if it follows the provisions of the applicable regulations. A request to cancel a marriage can be done if the marriage is under threat. Because marriage is a legal act it will have legal consequences.

Cancellation of marriage due to polygamy without permission from the court becomes the focus of discussion, related to a husband who will do polygamy must first follow the conditions stipulated by the Act. Conditions that must be met by the husband to be able to carry out polygamy is very closely related to permission from the wife. Based on article 4 of Law No. 1 of 1974 implies that permission can be given for a husband to have more than one wife if the wife cannot carry out her obligations as a wife, the wife has a disability or incurable disease, and the wife cannot give offspring.

After the conditions of the wife are met, the new husband can submit a request to the court by attaching a statement in accordance with the provisions of article 5 of the Marriage Law. The cancellation of a marriage as a result of polygamy without permission with the power of being in the hands of the court in giving decisions also has to look at the other side. Paying attention to the protection of the rights to the wife and children as a result of the decision must also be highlighted, both from a legal perspective.

The cancellation of a marriage made by the first wife as a legal wife related to her husband's marriage which was carried out without permission, is sure to have legal consequences on the parties. This will relate to the form of legal protection for the parties in the cancellation of the marriage. The theoretical foundation relating to the annulment of marriage is the theory of legal protection. Legal protection as a guarantee of human rights and obligations in the context of fulfilling one's own interests and in relations with other human beings. ${ }^{1}$

In this regard, legal subjects who must receive legal protection are children and wives as a result of marriage annulment. Protection activities are not a monopoly of a person or a private or government body / organization and are not without mutual understanding of each other. But the common interests, with the aim of protecting those directed to the ability and carrying out a sense of achievement so that it is beneficial in national development. ${ }^{2}$

1 Turatmiyah. S. M. Syaifuddin., \& Novera, A, Akibat Hukum Pembatalan Perkawinan dalam Perspektif Hukum Perlindungan Anak dan Perempuan di Pengadilan Agama Sumatera Selatan, Ius Quia Iustum 22(1), 2015, p. 167

2 Ibid. 


\section{PROCEDURES FOR OBTAINING POLYGINE LICENSES IN RELIGIOUS COURT}

Quoting the writings of Yudith Ika Pratama and friends who are discussing the cancellation of the marriage means that the marriage that has been done is an illegitimate event, or is considered to be nonexistent $^{3}$, from the perspective of the LBH Apik Foundation said so.

An application for a marriage cancellation can be submitted by a husband or wife. Cancellation of marriage referred to here is the cancellation of a marriage due to the occurrence of polygamy without permission. Requirements for a marriage to be canceled if there is polygamy by the husband without permission from the religious court, the woman who wants to be married after being traced is still the legal wife of another person.

A marriage can be canceled if one of the parties cannot fulfill the conditions for a marriage, this is clearly regulated in article 22 of the Marriage Law. However, the focus of this discussion is aimed at canceling marriages due to the provisions of the regulations that govern them, the following are provisions to be able to cancel marriages: first marriages can be canceled if there is a threat or even coercion that violates the law in Indonesia (regulated in article 27 Law No. 1 of 1974 concerning marriage); secondly, at the beginning of marriage there is a falsification of identity regarding marital status, age of marriage, even beliefs or religious beliefs (regulated in article 27 of the Marriage Law); third, husband or wife is still related to marriage with other people without the knowledge of any party (regulated in article 24 of the Marriage Law); fourth, a husband practices polygamy without the permission of the religious court (regulated in article 71 of the Compilation of Islamic Law); fifth, the woman who is married is still in the iddah or waiting period of her husband (regulated in article $71 \mathrm{KHI}$ ); sixth, the marriage takes place without any trusteeship or guardian who is not a trustee who is entitled (regulated in article $71 \mathrm{KHI}$ ); seventh, openly known that there are violations of the age of marriage (regulated in article 7 of the Marriage Law). a husband practices polygamy without the permission of the religious court (regulated in article 71 of the Compilation of Islamic Law); fifth, the woman who is married is still in the iddah or waiting period of her husband (regulated in article $71 \mathrm{KHI}$ ); sixth, the marriage takes place without any trusteeship or guardian who is not a trustee who is entitled (regulated in article $71 \mathrm{KHI}$ ); seventh,

3 Yudith Ika Pratama, Farida Prihatini, Endah Hartati, Tinjauan Yuridis Pembatalan Perkawinan Karena Tidak Terpenuhinya Jangka Waktu Tunggu (Masa 'Iddah) Menurut Kompilasi Hukum Islam dan Undang - Undang Perkawinan No. 1 Tahun 1974 (studi Kasus Putusan Mahkamah Agung No. 41 K/AG/2009, Jakarta: FH UI, 2014. 
openly known that there are violations of the age of marriage (regulated in article 7 of the Marriage Law). a husband practices polygamy without the permission of the religious court (regulated in article 71 of the Compilation of Islamic Law); fifth, the woman who is married is still in the iddah or waiting period of her husband (regulated in article $71 \mathrm{KHI}$ ); sixth, the marriage takes place without any trusteeship or guardian who is not a trustee who is entitled (regulated in article $71 \mathrm{KHI}$ ); seventh, openly known that there are violations of the age of marriage (regulated in article 7 of the Marriage Law).

Marriages committed violate the age limit of marriages as mentioned in Article 7 of the latest Marriage Law, which is for men and women with a minimum age of 19 years, marriages take place without a guardian or are carried out by unauthorized guardians, and marriages are carried out by force, and the woman is still in the iddah period.

For example, in the Decision of the Wonosobo Religious Court Number: 1175 / Pdt.G / 2011 / PA.Wsb., The Petitioner filed a request to cancel the marriage because the marriage between the Petitioner and the Respondent occurred because of an arranged marriage by the Petitioner's parents and was forced to get married. The Petitioner mentioned that he did not know the Respondent so well that the Petitioner did not love the Respondent. The Petitioner wants to marry the Respondent out of fear and wants to serve the Petitioner's parents. After marrying the Petitioner and Respondent lived together in the Respondent's parents' house for 2 weeks, then separated until now (at the time of this request) it has been 1 year. Upon the request, the Judge decided to grant the Petitioner's request and cancel the marriage of the Petitioner and the Respondent ${ }^{4}$.

The compulsion to get married can be one of the reasons for divorce. As in the Decision of the Bojonegoro Religious Court Number 1679 / Pdt.G / 2012 / PA.Bjn regarding the case for divorce divorce application. At first the Petitioners and Respondent never knew each other, never met each other, never liked each other because before the Petitioner's Marriage Agreement was still in the Islamic Boarding School. The Respondent has a mental retardation disease that should not be married by the Petitioner because at any time it could endanger the life of the Petitioner and his family. At the time of the Marriage Covenant, the Respondent was already 6 months pregnant which was not the result of a husband and wife relationship between the Petitioner and the Respondent but the result of the act of adultery with other men. The Petitioner was willing to marry the Respondent because he was under pressure so he was forced to approve it, ${ }^{5}$.

Marriage which is based on coercion of another person leads to the household of the Petitioner and the Respondent can no longer be

\footnotetext{
4 Hukumonline.com, Tentang Pembatalan Nikah dan Perceraian, https://www.hukumonline.com/klinik/detail/ulasan/lt55da9df734a73/tentangpembatalan-nikah-dan-perceraian/, 2015. Accessed on 19 November 2019

5 Ibid
} 


\section{Lestari \& Adiyatma}

reconciled and the parties do not mind if both are divorced. The judge finally decided to grant the Petitioner's petition and give permission to the Petitioner to drop divorce 1 ba'in sughro against before the Bojonegoro Religious Court Session 6 .

These seven conditions can be done to obtain the cancellation of the marriage, the cancellation of the marriage can be done in a religious court for adherents of Islam and a state court that adheres to non-Islamic religions. Procedures for canceling marriages in a religious court include:

1. Come to the Religious Courts (PA) for Muslims and the District Courts (PN) for non-Muslims in the area where both partners live. Cancellation of a marriage can not only be done by both partners but also the parents of both parties. (Law No.7 / 1989 article 73)

2. Then submit an application in writing or verbally to the Chief Justice. (HIR article 118 paragraph (1) / Rbg article 142 paragraph (1))

3. Then pay the advance fee for the case to the Special Treasurer. Based on information from the religious court and district court in paying court fees

4. both partners must attend court in court based on a subpoena. However, it can be represented by a designated legal representative (Law No.7 / 1989 article 82 paragraph (2), PP No. 9/1975 articles 26.27 and 28 of Jo HIR articles 121.124 and 125)

5 . both partners personally or through their attorneys are obliged to prove the truth of the contents of the marriage cancellation request before a court hearing based on evidence in the form of letters, witnesses, confession of one party, judge's presumption or oath of one of the parties (HIR article 164 / Rbg article 268). Furthermore, the judge examined and decided the case.

6. Then both of them receive a copy of the PN or PA decision that does not yet have permanent legal force.

7. Only after receiving the deed of cancellation, as the applicant the party who submitted it or both immediately requested the abolition of marriage records in the register of the Office of Religious Affairs (KUA) or the Office of Civil Registration (KCS)

MM Pasaribu in his book entitled Indonesian Marriage Law concluded the procedure for requesting a marriage cancellation, that is ${ }^{7}$ :

1. The request for a marriage cancellation by the applicant or his attorney is submitted to the Court whose jurisdiction covers the area of residence of the respondent, the contents of which indicate his intention to cancel the marriage accompanied by the reasons used to demand the cancellation of the marriage (Article 38 paragraph (2) of the Marriage Law jo Article 20 PP No. 9 of 1975);

Ibid

Wahyono Darmabrata \& Surini Ahlan Sjarif, Hukum Perkawinan dan Keluarga di Indonesia, Depok: Badan Penerbitan Fakultas Hukum Universitas Indonesia, 2004, p. 59 
2. The court summoned the respondent in writing by attaching a request regarding the cancellation of the marriage, which must be submitted no later than 3 days before the trial hearing is conducted (Article 38 PP No. 9 of 1975 jo. Article 26 paragraph (4) PP No. 9 of 1975);

3. The court checks the request to cancel the marriage no later than 30 days after the request is submitted (Article 38 paragraph (2) in conjunction with Article 29 paragraph (1) PP No. 9 of 1975;

4. The court tried to reconcile the two parties and if peace could not be carried out then the examination was carried out in a closed session, while the decision was pronounced in an open trial;

5. If the Court's Decision has a permanent decision, the Court Clerk submits one sheet of the decision to the Registrar of Marriage, henceforth by the Registrar Registrar is recorded on the list intended for that purpose.

The cancellation of the marriage (non-Muslims) must be reported by residents who have experienced the cancellation of the marriage to the Implementing Agency or UPTD implementing agency no later than 90 (ninety) days after the court's decision regarding the cancellation of the marriage which has obtained permanent legal force. The Implementing Agency revokes the Marriage Certificate from the ownership of the subject of the marriage certificate. Based on the report, the Civil Registry Officer issues a Certificate of Cancellation of Deed and makes notes on the cancellation of the Deed, its requirements, including:

a. Husband and wife's KK and KTP

b. Court Ruling on Marriage Cancellation

For reporting fees of 0 to 90 days from the date on which the cancellation of the marriage is decided by the District Court, there is no fee or free. However, reporting more than 90 days after the marriage cancellation was decided by the District Court, a late sanction of Rp. 100 thousand based on Perda No. 9 of $2012^{8}$.

Conditions for cancellation of a marriage can be fulfilled, if it follows the provisions of the applicable regulations. A request to cancel a marriage can be done if the marriage is under threat. Because marriage is a legal act it will have legal consequences.

Cancellation of marriage due to polygamy without permission from the court becomes the focus of discussion, related to a husband who will do polygamy must first follow the conditions stipulated by the Act. Conditions that must be met by the husband to be able to carry out polygamy is very closely related to permission from the wife. Based on article 4 of Law No. 1 of 1974 implies that permission can be given for a husband to have more than one wife if the wife cannot carry out her

8 Rivaldi Ade Musliadi, Begini Prosedur Pembatalan perkawinan, https://pontianak.tribunnews.com/2019/04/18/begini-prosedur-pembatalanperkawinan, 2019. Accessed on 5 Desember 2019 


\section{Lestari \& Adiyatma}

obligations as a wife, the wife has a disability or incurable disease, and the wife cannot give offspring.

After the conditions of the wife are met, the new husband can submit a request to the court by attaching a statement in accordance with the provisions of article 5 of the Marriage Law. The cancellation of a marriage as a result of polygamy without permission with the power of being in the hands of the court in giving decisions also has to look at the other side. Paying attention to the protection of the rights to the wife and children as a result of the decision must also be highlighted, both in the perspective of the law. In addition, for the problem of polygamy can be seen in Government Regulation No. 10 of 1983 which specifically contains a permit for polygamy for civil servants. Article 4 emphasizes "that if a male Civil Servant will have more than one wife, he must obtain prior permission from the official".

A husband who works as a Civil Servant to obtain a polygamy permit must meet the requirements whose rules are almost similar to the Marriage Law, the requirements are as follows:

1. An alternative requirement is that because the wife cannot carry out her obligations as a wife, the wife gets a disability or an incurable disease, the wife cannot give birth to offspring.

2. Cumulative requirements are, there is written consent from the wife, the income of the Civil Servant concerned is sufficient to finance more than a wife and her children as evidenced by an Income Tax certificate and there is a written guarantee from the Civil Servant concerned that she will be fair to the wife and their children ".

\section{THE DECISION OF JUDGES ABOUT CANCELLATION OF MARRIAGE OF CHILD RIGHTS}

According to Satjipto Raharjo, legal protection is providing protection for human rights that are harmed by others and the protection is given to the community so that they can enjoy all the rights provided by the law or in other words legal protection is a variety of legal efforts that must be given by the enforcement apparatus the law to provide a sense of security, both mental and physical from harassment and various threats from any party. ${ }^{9}$

Protection of children against marital problems is also seen as important, because the legal consequences of marriage have an impact on child development. Based on Article 23 of Law No. 1 of 1974 determines that those who can apply for marriage are: a. Families in a straight line up from husband or wife; b. Husband or wife; c. The

9 Satjipto Raharjo, Ilmu Hukum, Bandung, Citra Aditya Bakti, 2000. p. 53 
authorized official only during the marriage has not been decided yet; $d$. The designated official paragraph (2) Article 16 of this Law and any person who has a direct legal interest in the marriage, but only after the marriage is terminated. Cancellation of marriage must receive the attention of various parties involved, because it affects children and wives. Children who are certainly many victims of marriages by their parents are canceled, ${ }^{10}$.

Decisions from religious court or district court judges are not retroactive ${ }^{11}$ :

a. Children born from such marriages;

b. a husband or wife who acts in good faith, except for joint property, if the cancellation of the marriage is based on the existence of another marriage;

c. other third parties are not included in $\mathrm{a}$ and $\mathrm{b}$ as long as they obtain rights in good faith before the decision on cancellation has permanent legal force.

As a result of the marriage cancellation statement regulated in article 28 of the Marriage Law as well as articles 95 to 98 of the Civil Code, it was stated by R. Soetojo Prawirohamidjojo and Marthalena Pohan containing the points of good faith from husband and wife; only one party in good faith; and no one in good faith ${ }^{12}$.

The meaning of good faith from husband and wife is related to the legal consequences that will be caused. Through good faith the marriage is still declared valid so that it can be said to be almost similar to divorce. As a result of this good faith, the rights of children can be perfectly protected, because both the husband and wife must jointly support their children materially and formally. The annulment of marriage with good faith in it implies that from a court decision that changes only the status of the marriage, so that before there is a decision both are still considered valid because they are different from divorce through divorce both of them can still live at home. On the other hand, assets acquired during a marriage until the verdict is issued will be divided equally to be privately owned by a husband and wife whose marriage has been canceled. It is different if the marriage is related to the distribution of assets arranged and made an agreement between the two parties. Whereas the children obtained are considered as endorsement of the child outside marriage and adoption $^{13}$.

The meaning of only a party in good faith, a marriage that occurs with only one party in good faith is only beneficial to the party in good faith and children only and does not affect the party that is not in good

10 Turatmiyah, Op.Cit. p. 174

11 Article 28 of Law No. 1 of 1974

12 R.S. Prawirohamidjojo. M. Pohan, Hukum Orang dan Keluarga (Personen en Familie Recht), Surabaya, Airlangga University Press. p. 38

13 Ibid 


\section{Lestari \& Adiyatma}

faith, so that the party is burdened by costs, compensation and flower ${ }^{14}$. From the process of distributing the assets of those in good faith if they have a small amount of assets, the assets distributed with a decision to cancel a marriage will increase and vice versa if the assets of those in good faith will not be distributed to inheritance. And the position of the child from the marriage annulment with a good will will be considered a legitimate child ${ }^{15}$.

The meaning of the lack of good faith from both husband and wife, their marriage will be considered truly never happened so that there is no process of pooling the assets obtained during the marriage and the children born during the marriage will be considered as extramarital children. Efforts to cancel polygamy are actually included in the framework of increasing the status of women, because basically the parties most disadvantaged by the occurrence of illegal polygamy are women. If examined more closely, the provisions of Article 71 Letter (a) constitute a further step in the discussion of polygamy in Article 56 Paragraph (1), in which a husband who wishes to have more than one wife is required to obtain permission from the Religious Court ${ }^{16}$. That is, the existence of a polygamy marriage that can be canceled originated from violations of the provisions of the KHI, especially Article 56 Paragraph (1). The availability of Article 71 Letter (a) with the term preventive and solutive measures. On one hand, this article is a kind of strong warning for husbands who will commit illegal polygamy. And on the other hand, it becomes a way out for illegal polygamy which is already underway ${ }^{17}$.

Children's civil rights must not be ignored, so efforts are needed to provide guarantees for the maintenance of children's civil rights. The judiciary in this case has an important role to guarantee the civil rights of children through its decisions. Because children born from such marriages must be protected and concerned about their welfare and interests, because children are the ones who feel the consequences. The decision to cancel the marriage aims to end or resolve a dispute when violations of rights are felt ${ }^{18}$.

The position of a child from a marriage cancellation depends on the goodwill of both parents, so the rights obtained due to the cancellation of the marriage are adjusted to that intention. Because the court's decision is not retroactive in the sense that the court's decision to cancel the marriage applies when the court's decision has permanent legal force. Thus, even though the marriage is not legal, because this marriage is

\footnotetext{
14 Ibid

15 Ibid

16 Direktorat Jenderal Pembinaan Kelembagaan Agama Islam, Kompilasi Hukum Islam, p. 34.

17 Abdul Holik, "Pembatalan Perkawinan Akibat Poligami", Tafaqquh 1(2), 2013, p. 62

18 Ibid
} 
carried out in good faith, it is given an exception in the case of joint assets obtained during the marriage, ie after the marriage is canceled, each exhusband and ex-wife continue to obtain joint property. ${ }^{19}$.

The position of children born and will be born as a result of the cancellation of marriage according to Article 28 Paragraph (2) letter a of the Marriage Law which states that: "The decision is not retroactive to: Children born from the marriage". Children born from a canceled marriage are still considered legitimate children. So that a canceled marriage does not erase the parents 'responsibilities towards the child born or to be born and is entitled to the care, financing and inheritance of the parents' family ${ }^{20}$. In other words, children and parents still have alimony relationships. This is also confirmed in Article 26 Paragraph (1) of Law Number 23 Year 2002 Regarding Child Protection (hereinafter referred to as the Child Protection Act) which states that: "Parents are obliged and responsible for:

a. nurture, nurture, educate and protect children;

b. developing children according to their abilities, talents, and interests;

c. prevent marriages at the age of children ".

Assumptions regarding the responsibilities of a father and mother will not cease even though the marriage has ended due to divorce or marriage cancellation. This is based on article 76 states: "The cancellation of a marriage will not break the legal relationship between the child and his parents" 21 . The rights of the child will be protected because of the good will of both parents, due to the retroactive effect of the law on the case of the cancellation of the marriage due to polygamy. At least the good faith that is expected for the continuity of a child to be able to live his life without the influence of the separation of his parents is still aimed at the good faith of the husband and wife related to the legal consequences that will arise and only a party from both to have good intentions. The right to be cared for by his own parents is a right that must be obtained by the child, therefore Article 14 of the Child Protection Act provides legal certainty for children who experience the split of their parents' household.

Unless there is a reason and / or law that shows that separation is in the best interest of the child and is the last consideration, as Muhammad Joni views in the thesisSiti Kholisotun Ni'mah, this exception is emphasized. But the meaning of the interests of children can occur if polygamy without permission from the father influences the

19 Alfian Jauhari Hanif, “Akibat Hukum Kedudukan Anak dan Harta Bersama Setelah Adanya Pembatalan Perkawinan Oleh Pengadilan Agama Yogyakarta", Thesis, Unpublished Work, Yogyakarta, Universitas Muhammadiyah, 2009, p. 94.

20 Kadek Deni Risma Midarini, Ketut Sudiatmaka \& Ratna Artha Windari, Tinjauan Yuridis Kedudukan Anak Akibat Pembatalan Perkawinan Berdasarkan Undang Undang Nomor 1 Tahun 1974, E-Journal Komunitas Yustisia 2 (1), 2019

21 Abdul Gani Abdullah, Pengantar Kompilasi Hukum Islam dalam Tata Hukum Indonesia, Jakarta, Gema Insani Press, 1994, pp. 97-100. 


\section{Lestari \& Adiyatma}

child's future, if it is seen as very difficult to believe because the cancellation of the marriage the main movers are the mother because there is a right as a wife violated to give permission even not to be combined. In principle, the state makes efforts to keep children in the care of their own parents, and not separated from parents in opposition to the wishes of the child. In this article it is emphasized that the child has the right not to be separated from his parents against the will of the child, unless the intended separation has legal reasons, and is carried out in the best interests of the child. ${ }^{22}$ Besides that, it is a result of a marriage being canceled by covering a child's good will, like a biological child and a legitimate child. Another case if there is no good faith children from the outcome of marriage will be likened to children outside of marriage.

Even though the marriage has been canceled, parents still have obligations to the child they gave birth to. That parents are obliged to look after and educate their children as well as possible (Article 45 paragraph (1) of Law Number 1 of 1974 concerning Marriage), where as parents have an obligation to care for their children that is meeting all their needs and providing the best education for children in accordance with the abilities possessed by each parent and educate children to grow into good children despite having parents who have separated. Parents' obligations apply until the child marries or can stand alone. The obligation continues even though the marriage between the two parents breaks up (Article 45 paragraph (2) of Law Number 1 of 1974 concerning Marriage). ${ }^{23}$

\section{CONCLUSION}

The annulment of a marriage makes marital status considered unheard of, even though the concept is the same as divorce, as does the marital status. The similarity between the two children's rights will continue to be fulfilled by both parents. But in contrast to the cancellation of the marriage this is determined by the application of good faith which is used as stated by R. Soetojo Prawirohamidjojo and Marthalena Pohan, the author of the quote from ThesisSiti Kholisotun Ni'mahcontains the principal points of good faith from husband and wife; only one party in good faith; and no one in good faith. The rights of children will be obtained as long as good faith is done from both parents or one of them, if no one does good faith towards the child from the marriage, a child will have the same position as a child born out of wedlock. Procedure for submitting an application for a marriage cancellation must be carried out

22 Siti Kholisotun Ni'mah, "Analisis Yuridis Terhadap Pemenuhan Hak-Hak Anak Di Panti Asuhan Nurul Falah Jemur Wonosari Surabaya", Thesis, Surabaya, UIN Sunan Ampel, 2015. p. 26

23 Noca Cumala Amina Nurhuda, "Proses Penyelesaian Perkara Pembatalan Perkawinan Sepersusuan dan Akibat Hukum Terhadap Anak yang Dilahirkan”, Thesis, , Surakarta, Universitas Muhammadiyah Surakarta, 2017. 
in a religious court or district court because both have the authority to decide, the choice of court environment is determined by the religion they hold. Like an agreement, a marriage based on the agreement of both parties has a legal effect that is very influential for the future of the child or wife.

\section{REFERENCES}

Compilation of Islam Law [Direktorat Jenderal Pembinaan Kelembagaan Agama Islam. Kompilasi Hukum Islam].

Darmabrata, W., \& Sjarif, S. A. (2004). Hukum Perkawinan dan Keluarga di Indonesia. Depok: Badan Penerbitan Fakultas Hukum Universitas Indonesia

Hanif, A. J. (2009). Akibat Hukum Kedudukan Anak dan Harta Bersama Setelah Adanya Pembatalan Perkawinan Oleh Pengadilan Agama Yogyakarta. Thesis, Unpublished Work. Yogyakarta: Universitas Muhammadiyah Yogyakarta.

Holik, A. (2013). Pembatalan Perkawinan Akibat Poligami. Tafaqquh $1(2), 58-72$.

Hukumonline. (2015). Tentang Pembatalan Nikah dan Perceraian. https://www.hukumonline.com/klinik/detail/ulasan/lt55da9df734a 73/tentang-pembatalan-nikah-dan-perceraian/. Accessed on 19 November 2019.

Indonesian Civil Code [Kitab Undang - Undang Hukum Perdata]

Musliadi, R. A. (2019). Begini Prosedur Pembatalan perkawinan, https://pontianak.tribunnews.com/2019/04/18/begini-prosedurpembatalan-perkawinan. Accessed on 5 December 2019.

Ni'mah, S. K. (2015). Analisis Yuridis Terhadap Pemenuhan HakHak Anak Di Panti Asuhan Nurul Falah Jemur Wonosari Surabaya. Thesis. Surabaya: UIN Sunan Ampel.

Nurhuda, N. C. A. (2017). Proses Penyelesaian Perkara Pembatalan Perkawinan Sepersusuan dan Akibat Hukum Terhadap Anak yang Dilahirkan. Thesis. Surakarta: Universitas Muhammadiyah Surakarta

Pratama, Y. I., Prihatini, F., \& Hartati, E. (2014). Tinjauan Yuridis Pembatalan Perkawinan Karena Tidak Terpenuhinya Jangka Waktu Tunggu (Masa 'Iddah) Menurut Kompilasi Hukum Islam dan Undang - Undang Perkawinan No. 1 Tahun 1974 (Studi Kasus Putusan Mahkamah Agung No. 41 K/AG/2009. Thesis. Jakarta: Universitas Indonesia.

Prawirohamidjojo, R.S., \& Pohan, M. (1991). Hukum Orang dan Keluarga (Personen en Familie-Recht). Surabaya: Airlangga University Press.

Rahardjo, S. (2000). Ilmu Hukum. Bandung: Citra Aditya Bakti. 


\section{Lestari \& Adiyatma}

Republic of Indonesia. (1945). The 1945 Constitution of the Republic of Indonesia [Undang-Undang Dasar Negara Republik Indonesia Tahun 1945]

Republic of Indonesia. (1974). Law No. 11974 About Marriage [Undang-Undang No. 1 Tahun 1974 Tentang Perkawinan]

Republic of Indonesia. (2019 Law No. 16 of 2019 On Amendment to Law No. 11974 About Marriage [Undang-Undang No. 16 Tahun 2019 Tentang Perubahan Undang-Undang No. 1 Tahun 1974 Tentang Perkawinan]

Republic of Indonesia. (2002). Law Number 23 of 2002 concerning Child Protection [Undang-undang Nomor 23 Tahun 2002 Tentang Perlindungan Anak]

Republic of Indonesia. (1990). Government Regulation No. 45 of 1990 concerning Amendment to Government Regulation No. 10 of 1983 concerning Marriage and Divorce Permits for Civil Servants [Peraturan Pemerintah No. 45 Tahun 1990 Tentang Perubahan Peraturan Pemerintah No. 10 Tahun 1983 Tentang Izin Perkawinan dan Perceraian Bagi Pegawai Negeri Sipil]

Turatmiyah, S., Syaifuddin, M., \& Novera, A. (2015). Akibat Hukum Pembatalan Perkawinan dalam Perspektif Hukum Perlindungan Anak dan Perempuan di Pengadilan Agama Sumatera Selatan. Ius Quia Iustum 22 (1), 163-179. 